Teologia i Moralność, volumen 12(2017), numer 1(21)

doi: 10.14746/tim.2017.21.1.9

JUSTYNA NOWICKA

Uniwersytet im. Adama Mickiewicza w Poznaniu

Wydział Teologiczny

\title{
Teologia codzienności Karla Rahnera jako odpowiedź na duchowe potrzeby czlowieka w postmodernistycznym świecie
}

Postmodernizm jest zjawiskiem bardzo rozległym i złożonym. Dotyczy takich dziedzin, jak: kultura, filozofia, sztuka, architektura, literatura, nauki społeczne, historia. Ze względu na temat pracy, który dotyczy możliwości prowadzenia życia duchowego we współczesnym świecie, najbliższy zakresowi niniejszego artykułu jest postmodernizm rozumiany jako fakt społeczno-kulturowy oraz filozoficzny. $Z$ tego też powodu konieczne będzie dokonanie pewnych uogólnień, by wyodrębnić najważniejsze, wspólne idee.

Następnie zostanie przybliżone pojęcie i zjawisko duchowości postmodernistycznej. To pozwoli głębiej zastanowić się nad pytaniem, czy możliwa jest teologia we współczesnym świecie, zwłaszcza czy możliwa jest teologia duchowości, która nie powinna pozostawać jedynie na płaszczyźnie teoretycznej czy spekulatywnej, ale powinna być możliwa do przełożenia na praktykę życia oraz stać się trafną propozycją dla współczesnego człowieka.

W dalszym etapie pracy podejmę próbę określenia, jakie ujęcie teologii życia nadprzyrodzonego będzie mogło być przyjęte i internalizowane przez człowieka kształtowanego w dużej mierze w postmodernistycznej rzeczywistości, ale także odkrywającego w sobie tęsknotę za Bogiem i życiem duchowym. W tym celu omówię teologię codzienności postulowaną przez Karla Rahnera.

Przy omawianiu wskazanego zagadnienia posłużę się trzema metodami stosowanymi w teologii duchowości: opisową, dedukcyjną oraz fenomenologiczną. 


\section{Postmodernizm - terminologia i charakterystyka zjawiska}

Pojęcie postmodernizm jest używane w bardzo szerokim zakresie, przy czym ,nie chodzi tu nie tyle o same terminy, ile raczej o cały szereg poglądów na kulturę, religię, społeczeństwo, człowieka, naturę, filozofię itd."1. Nie ma zgodności wśród badaczy współczesności co do stosowania jednolitej nomenklatury. Niektórzy używają zamiennie takich pojęć jak ponowoczesność, postmodernizm, inni natomiast każdemu z nich przypisują nieco inny zakres. Będę używała terminu postmodernizm, ponieważ niezależnie od rozbieżności jest on używany przez większość specjalistów czy to w szerszym (do opisu ogółu przemian we współczesności), czy to w węższym kontekście (do opisu przemian zachodzących w dziedzinie pytań o rozum i racjonalność, zagadnienie podmiotu, rolę poprzedniej epoki dla obecnego kształtu rzeczywistości społeczno-kulturowej, podstawowych wartości życia codziennego jednostki, postaw, obyczajowości) ${ }^{2}$. Można też dostrzec dużą zgodność, jeśli chodzi o stosowanie tego terminu do charakterystyki aktualnie dokonujących się zmian społeczno-kulturowych.

Najważniejszą cechą postmodernizmu jest programowy antyracjonalizm. Postawa ta wynika z rozczarowania światem, w którym nastąpił gwałtowny rozwój naukowo-techniczny. Postmoderniści mówią o tym, że współczesność jest mitem, gdzie wciąż obecna jest utopijna wiara w realizację wielkich celów, takich jak: likwidacja głodu na świecie, sprawiedliwość społeczna, demokracja i pokój. Tymczasem obszary głodu wciąż są znaczne, dyktatury polityczne się odradzają, wybuchają wojny i nowe konflikty. Postmodernizm jest więc krytyczną reakcją na naiwną wiarę w postęp ${ }^{3}$. Wyraża odczucia i przekonania o nowożytnym upadku idei, który jest przejawem „kryzysu totalnego, paraliżującego, zapowiadającego koniec historii, negującego istnienie wrażliwości zdolnej do znalezienia jakiegoś telos, jakiegoś celu czy sensu w chaotycznym natłoku

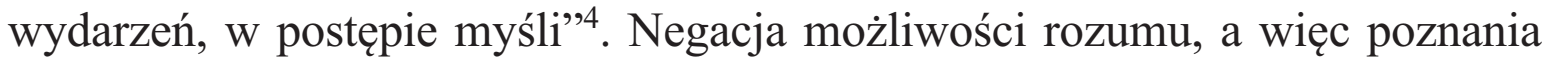
ostatecznych podstaw istnienia i wartości świata najpełniej wyraża się w nihilizmie i agnostycyzmie poznawczym. $Z$ tego niejako naturalnie wynika zwrot ku absolutyzowaniu indywidualizmu, odrzucaniu obiektywnego sensu rzeczywistości czy teologicznej wizji świata, ku negowaniu zasady jedności i uniwersalności, deprecjonowaniu kulturowego i społecznego wymiaru egzystencji ${ }^{5}$.

1 Z. Pawlak, Filozoficzne aspekty ruchu postmodernistycznego, w: Globalopolis. Kosmiczna wioska. Szanse i zagrożenia, red. R. Borkowski, Warszawa 2003, s. 30.

2 Por. B. Guzowska, Duchowość ponowoczesna, idee, perspektywy, prognozy, Rzeszów 2011, s. 68.

3 Por. J. Dębowski, Postmodernizm a religia, „Res Humana” 4(1995), s. 34-36.

4 J.J. Garrido, Misja chrześcijanina w czasach kryzysu kultury, „Communio” 1994, nr 6, s. 76.

5 Por. Z. Sareło, Postmodernistyczny styl myślenia i życia, w: Postmodernizm wyzwanie dla chrześcijaństwa, red. tenże, Poznań 1995, s. 10. 
Filozofia postmodernistyczna zakłada niepowtarzalność ludzkiego myślenia, poznawania i wartościowania ${ }^{6}$. Prowadzi to jednak do usunięcia z życia człowieka wyższych wartości, w tym prawdy i sacrum. Odebranie osobie duchowego centrum skutkuje poczuciem pustki, bezsensu i lęku przed utratą sensu ostatecznego, sensu istnienia. Współczesny człowiek nie dostrzega immanentnego sensu, bo nie ma jednoznacznych kryteriów, według których może ocenić, czy proponowane mu przez różne ośrodki indoktrynacji sposoby jego rozumienia są prawdziwe, może go jedynie subiektywnie nadawać ${ }^{7}$. To prowadzi do ukształtowania człowieka ,wybitnie nieodpornego i słabego, nieprzygotowanego do pokonywania trudności, skłonnego do zniechęcenia albo załamania w obliczu najmniejszych przeciwności losu"8. Indywidualizm, a co za tym idzie, skrajny pluralizm zasad i wartości prowadzi do zatomizowania społeczeństwa. Więzi społeczne zostają rozluźnione, ludzie nie mają potrzeby nawiązywania głębszych emocjonalnych relacji. Jednostki wchodzą w nie tylko dla doraźnych celów9

Dalszą konsekwencją negowania możliwości poznania rozumowego i immanentnej prawdy jest przekonanie, że wszelka wiedza jest niedoskonała, paradoksalna, nieciągła. Ta tendencja do fragmentaryzowania rzeczywistości prowadzi do spojrzenia na świat jako na zbiór chaotycznie zebranych elementów bez jakiegokolwiek zakorzenienia i fundamentu ${ }^{10}$. Fragmentarycznie bywa też postrzegany czas, jako zbiór momentów, między którymi nie ma ciągłości ${ }^{11}$. Nie istnieje zatem ani przeszłość, ani przyszłość. Człowiek żyje tylko w teraźniejszości; ważne jest, by doznać jak najwięcej wrażeń, żyje w świecie, w którym niczego nie robi się na zawsze, nie ma w nim żadnych pewników ekonomicznych, religijnych czy naukowych. Dominuje niepewność zarówno w odniesieniu do materialnego, jak i duchowego wymiaru obecnej rzeczywistości ${ }^{12}$.

Upowszechnienie postmodernistycznego stylu myślenia odbywa się przede wszystkim za pomocą środków masowego przekazu ${ }^{13}$. Wykorzystując to, że człowiek współczesny jest zafascynowany obrazami, instytucje tworzące reklamę, wystawy sklepowe, mass media posługują się rynkową manipulacją, by przemodelować ludzkie pragnienia. Są one sztucznie kreowane, a jedno-

\footnotetext{
6 Por. B. Baran, Postmodernizm, Kraków 1992, s. 196.

7 Por. J.A. Lata, Lęk przed pustka i bezsensem, „Communio” 1994, nr 6, s. 41-43.

8 J.F. Lyotard, La postmodernidad explicade, cyt. za: J.J. Garrido, Misja chrześcijanina w czasach kryzysu kultury, „Communio” 1994, nr 6, s. 79.

9 Por. Z. Sareło, Postmodernistyczny styl myślenia i życia, dz. cyt., s. 15.

10 Por. S. Morawski, W mrokach postmodernizmu. Rozmyślania rekolekcyjne, w: Dokąd zmierza współczesna humanistyka?, red. T. Kostyrko, Warszawa 1994, s. 33.

11 Por. Z. Bauman, Dwa szkice o moralności ponowoczesnej, Warszawa 1994, s. 14n.

12 Por. tenże, Ponowoczesność jako źródło cierpień, Warszawa 2000, s. 44.

13 Por. B. Baran, Postmodernizm, Kraków 1992, s. 200.
} 
cześnie przyjmowane przez odbiorce jako realne, przez co traci on kontakt z rzeczywistym światem. Wszystkie komunikaty i treści są oderwane od rzeczywistości (są tzw. symulakrami) ${ }^{14}$, znakami bez odniesienia, tworząc pewnego rodzaju hiperrzeczywistość.

Przemiany zachodzą także w sferze religijności. Mają one szczególne nasilenie w społeczeństwach wysokorozwiniętych. W nurcie postmoderny istnieje pojęcie „duchowości postmodernistycznej”. „Należy [ją] rozumieć nie tylko jako duchowość religijną, opartą na sferze sacrum i uznaniu transcendencji, lecz także szerzej - jak formę życia duchowego wyrażającą się w określonym stylu życia"15. Religijność wymaga radykalnego wyboru, jest zindywidualizowana, podmiotowa. Efektem tego jest wzrost popularności nowych form religijnych, a także zakwestionowanie tradycyjnych wartości, norm moralnych i autorytetu Kościoła. Częste jest także otwarcie na nieeuropejskie kultury i religie $^{16}$. Charakterystyczną cechą ponowoczesności jest też rozwój irracjonalnych systemów myśli, w tym grup kulturowych, nowych ruchów religijnych, filozofii z kręgu New Age. Ta ostatnia jest reprezentatywnym zjawiskiem, będącym efektem przemian w sferach: religijności, społeczno-kulturowej i filozoficznej ${ }^{17}$.

Synkretyzm oraz tendencje prywatyzacyjne powodują, że jednostka wybiera różne elementy różnych ,systemów sensu”: nauki, ideologii, światopoglądu ukazywanego przez reklamy, tradycji regionalnych itp. ${ }^{18}$, i komponuje swoim osobistym wysiłkiem z różnych składowych „koktajlową wiarę”. Jest to nowa tak zwana sprywatyzowana, niedogmatyczna, niewidzialna forma religii $^{19}$, która zawiera $\mathrm{w}$ sobie to, co subiektywne, nie ma konwencjonalnej formy organizacji religijnej, nie jest reprezentowana przez instytucje, nie celebruje się w niej rytuałów czy dogmatów. „Sacrum powróciło i powraca wielką, potężną falą, ale - jak powiadają niektórzy historycy religii czy socjologowie - jest to dzikie sacrum. [...] powraca jako odnowienie tradycji ezoterycznej"20. Homogeniczne wspólnoty, religijne rodziny, różne formy aktywności społecznej, w której więź kościelna i religijna odgrywała znaczną rolę, tracą na znaczeniu ze względu na dużą społeczną mobilność i przekształcenia we wzorach życia i komunikacji albo stają się dysfunkcjonalne ze względu na dążenie ludzi do wartości świeckich. $Z$ drugiej strony pojawiają się nowe,

14 Por. B. Baran, Postmodernizm i końce wieku, Kraków 2003, s. 238.

15 B. Guzowska, Duchowość ponowoczesna..., dz. cyt., s. 9.

16 Por. tamże, s. 103; por. Franciszek, Evangelii gaudium 63, Częstochowa 2013, s. 56.

17 Por. B. Guzowska, Duchowość ponowoczesna..., dz. cyt., s. 11.

18 Por. F.X. Kaufmann, Die Rolle der Religion in mitteleuropäischen Gesellschaften, w: Lateinamerika und Europa, Dialog der Theologen, München 1988, s. 76-79, cyt. za: J. Mariański, Pozakościelne formy religijności, w: Postmodernizm wyzwanie dla chrześcijaństwa, dz. cyt., s. 60.

19 Por. T. Luckmann, Niewidzialna religia, tłum. L. Bluszcz, Kraków 2006, s. 60.

20 J.A. Kłoczowski, Chrześcijanin XXI wieku, „Znak” 1995, nr 3, s. 57. 
pozakościelne motywacje religijne. Przemawia za tym rosnąca liczba członków sekt oraz zainteresowanie nurtami mityczno-magicznymi połączonymi z ofertą psychologiczną ${ }^{21}$. Ruchy wywodzące się z nurtu New Age, który - jak powiedzieliśmy - jest transparentny dla duchowości ponowoczesnej, ,poszukują Transcendentnej Jedności religii. Mają one tendencję do wybierania z historycznych religii jedynie ich ezoterycznego jądra, za którego strażników się uważają. W jakiś sposób zaprzeczają historii i nie akceptują faktu, że duchowość może być zakorzeniona w czasie lub w jakiejś instytucji”"22.

W duchowości postmodernistycznej została wytworzona więc soteriologia popkulturowa, która obiecuje osiągnięcie szczęścia przez indywidualne odrzucenie religii i wyeliminowanie jej z życia społecznego ${ }^{23}$. Jeszcze w połowie $\mathrm{XX}$ wieku Kościoły chrześcijańskie pełniły funkcję autorytetu. $\mathrm{Z}$ tego powodu stały się powodem postmodernistycznej kontestacji, przy czym, gdy w modernizmie chodziło o kwestię Boga, to w postmodernizmie chodzi o pożyteczność religii jako takiej.

Postmodernizm jest wyzwaniem dla ukształtowanych na gruncie katolicyzmu oglądów rzeczywistości. Jest zjawiskiem, którego nie można pominąć, jeśli myślimy o nowej ewangelizacji czy życiu duchowym. „Nie chodzi przy tym o dostosowanie się do sposobu myślenia właściwego temu nurtowi, lecz o to, by mówić o Bogu Objawienia" 24 . Problemem pozostają jednak te radykalne propozycje postmodernizmu, w których usiłuje się wykazać, że akceptacja jakiejkolwiek prawdy jest formą zniewolenia umysłu i należy ją jako wartość odrzucić, by uniknąć tak zwanego imperializmu prawdy. W tej samej konwencji utrzymane są próby reinterpretacji wolności w kategoriach skrajnego indywidualizmu lub odrzucania tak zwanych wielkich narracji, czyli całościowych wizji życia ${ }^{25}$.

Nie można zaprzeczyć temu, że

człowiek nie jest w stanie radykalnie wyzwolić się spod wpływu kultury na myślenie i działanie, nawet jeżeli werbalnie deklaruje swoją absolutną autonomiczność. Kultura, w której człowiek wyrósł, w istotnej mierze determinuje jego rozumienie sensu siebie i świata, a także akceptowaną przez niego hierarchię wartości [...]. Z drugiej zaś strony, każde ludzkie działanie posiada wpływ na środowisko społeczne. Swoim działaniem człowiek tworzy lub niszczy kulturę ${ }^{26}$.

${ }^{21}$ Por. J. Mariański, Pozakościelne formy religijności, dz. cyt., s. 61.

22 Papieska Rada Kultury, Papieska Rada ds. Dialogu Międzyreligijnego, Jezus Chrystus dawca wody żywej. Chrześcijańska refleksja na temat New Age, Kraków 2003, s. 62.

${ }^{23}$ Por. G. Strzelczyk, Po co zbawienie? Po co Kościót?, w: Wielkie tematy teologii, red. E. Kiedo, Z. Nosowski, Warszawa 2015, s. 25-26.

${ }^{24}$ J. van der Vloet, Wiara wobec wyzwań postmodernizmu, „Communio” 1994, nr 6, s. 67.

25 Por. J. Życiński, Bóg postmodernistów, Lublin 2001, s. 80.

26 Z. Sareło, Postmodernistyczny styl myślenia i życia, dz. cyt., s. 25. 
Dlatego chrześcijaństwo musi być wyczulone na zmiany historyczne, społeczne i kulturowe. Trzeba spojrzeć „w twarz temu naszemu światu, spojrzeć na jego wartości i problemy, niepokoje i nadzieje, osiągnięcia i porażki"27. W nawiązaniu do obecnej sytuacji Jan Paweł II stwierdził, że

jedną z najjaskrawszych słabości obecnej cywilizacji jest nieodpowiednia wizja człowieka. Epoka nasza [...] jest epoką humanizmów i antropocentryzmu. Mimo to, paradoksalnie, jest ona również epoką najgłębszych utrapień człowieka, dotyczących jego tożsamości i jego przeznaczenia, epoką niepodejrzewanych dotąd degradacji człowieka, epoką deptania ludzkich wartości jak nigdy przedtem ${ }^{28}$.

Prowadzi to do zagubienia człowieka i nadziei. Dlatego papież mówi o ludziach współczesnych: „Ich jedynym pewnikiem jest to, że nie ma już żadnej ostatecznej prawdy, żadnej pewnej drogi. Świadomie lub nie, bronią postawy życiowej pogrążającej [...] w smutku i samotności, która odbiera [...] podstawy do nadziei i zdolność prawdziwej miłości”29. I chociaż „pozytywnym owocem ponowoczesności jest zdemaskowanie fałszywych nadziei modernizmu. Niestety, nie proponuje się niczego w zamian. Trudno bowiem uznać za pozytywną propozycję wezwania do stanowienia prawdy o sobie w absolutnej wolności" ${ }^{30}$. W takiej sytuacji nierzadko pojawia się postawa egzystencjalnej rozpaczy, wypływająca z rozczarowania systemami, które urzekały człowieka nową wizją nieba i ziemi. Objawia się to między innymi zanegowaniem sensu życia, kryzysem rodziny, ucieczką w używki ${ }^{31}$. Na gruncie tego przekonania możemy powiedzieć, że dewaluacja postępu może być przyczyną wyjścia współczesnego człowieka z indywidualizmu, by odnaleźć sens relacji z drugim człowiekiem i Absolutem.

Czymś naturalnym jest, że jednostki nieustannie przekraczają kanony zachowań i wartości. Jakiś sposób życia, który uchodzi za niekonwencjonalny, staje się coraz bardziej popularny; z czasem prowadzi to do upowszechnienia i odrzucenia starego wzorca. Podobnie wartości - niektóre tracą na znaczeniu, ponieważ były adekwatne do minionych już warunków życia. Jednak w gruncie rzeczy kwestionowany jest jedynie sposób, w jaki są sformułowane, a nie

27 Jan Paweł II, Christifideles laici, nr 3, http://www.opoka.org.pl/biblioteka/W/WP/jan_pawel ii/adhortacje/christifideles.html [dostęp: 17.10.2017].

28 Jan Paweł II, Przemówienie, Puebla, 28.01.1979, 20, Dzieła zebrane, t XII, Kraków 2009, s. 280.

29 Jan Paweł II, Przemówienie, Manila, 14.01.1995, 2, http://nauczaniejp2.pl/dokumenty/wy swietl/id/688 [dostęp: 17.10.2017].

30 Z. Sareło, Postmodernistyczny styl myślenia i życia..., dz. cyt., s. 20.

31 Por. Franciszek, Evangelii gaudium, 66, Częstochowa 2013, s. 58. 
one same. Trzeba ująć je w inny sposób, ponieważ wraz z przemianami może zanikać podstawa ich znaczeń ${ }^{32}$.

\section{Możliwość teologii w postmodernistycznym świecie. Próba wskazania kierunku refleksji teologicznej we współczesnej sytuacji egzystencjalnej}

Czy człowiek ukształtowany przez postmodernistyczne idee jest w ogóle w stanie uznać Boga? Czy możliwa jest komunikacja między tymi dwoma światami? Czy może być odbiorcą i twórcą teologii? Czy może opierać się na danych objawienia? Czy te dwa światy mogą się wzajemnie zrozumieć? A może któryś z nich należałoby porzucić? Jeśli porzucić, to który i dlaczego? Czy możliwe jest, aby teolog zinterpretował postmodernizm? Czy to go nie przerasta? Nawet gdyby tak było, to teolog jest zobowiązany, przez wzbudzającego jego powołanie Ducha Świętego, do podejmowania zadań, które niejako go przekraczają. Dlatego musi podejmować wciąż nowe próby zaangażowania się na rzecz zbawienia człowieka postmodernizmu. Jest też zobowiązany do tego, ponieważ ,dobra teologia musi być teologią dla człowieka, i to człowieka konkretnego, który przeżywa swoją historię zbawienia w określonym kontekście historycznym, politycznym, ekonomicznym, społecznym i kulturowym" ${ }^{33}$. Zadaniem teologa jest więc takie włączenie w swoją pracę wyzwań, trudności i szans swojej epoki, aby teologia w bardzo konkretny sposób spotykała teraźniejszość. Niektórzy teologowie podejmowali próby mierzenia się z „duchem czasu”. W efekcie w drugiej połowie XIX wieku utworzyła się tendencja, by oddzielać wiarę chrześcijańską od „nowoczesnego myślenia”. W opracowaniach teologicznych dążono do osiągnięcia nienaruszalnej trwałości stwierdzeń. Sposób relacji ze światem został też podjęty na Soborze Watykańskim II, ale nadano mu już inny charakter: spotkania, dialogu, gotowości do wspólnego podejmowania odpowiedzialności za przyszłość. Ewangelia nie miała już służyć pouczeniu, krytyce i potępieniu, ale została podkreślona jako Dobra Nowina, która objaśniając rzeczywistość, wyzwala i uszczęśliwia. Warunkiem takiej zmiany mentalności było przyjęcie człowieka ze wszystkim, co składa się na jego życie, a więc: historią, strukturami i przemianami społecznymi, kulturą, językiem. Wymagało to procesu głębokiej odnowy, otwarcia refleksji nad wiarą i nowymi obszarami chrześcijańskiej praxis ${ }^{34}$. Nie można

32 Por. J.A. Lata, Lęk przed pustka i bezsensem, „Communio” 1994, nr 6, s. 44.

33 S.C. Napiórkowski, Jak uprawiać teologię, Wrocław 1994, s. 44.

34 Por. Z. Falczyński, Teologia w kontekście ponowoczesności, w: Postmodernizm wyzwanie dla chrześcijaństwa, dz. cyt., s. 100-101. 
podważyć tego, że chrześcijanie nie są tożsami z jakąś konkretną kulturą czy narodem, ale mają siłę, by tworzyć i kształtować narodowe i kulturowe wartości ${ }^{35}$. Hans Urs von Balthasar pisał, że „dla chrześcijanina dwie sprawy są oczywiste: wierze, opierającej się na Wcieleniu, nie wolno uciekać od świata; jednak wierze, która rodzi się całkowicie z inicjatywy Boga, jest zabronione każde usiłowanie wymuszania zbawienia własną mocą"36.

Ponowoczesność nie wyklucza możliwości religii i duchowości w ogóle. Zgodnie z procesem życia społecznego, który przebiega według schematu, gdzie na pewnym etapie odchodzi się od tego, co tradycyjne, często postrzegane jako przestarzałe, do tego, co nowoczesne, religia ulegałaby przemianom w zakresie jej formy i funkcji ${ }^{37}$.

Mimo tych wszystkich przemian człowiek pozostaje w końcu ciągle ten sam. Nie byłoby tak wielu wierzących, gdyby ciągle ludzie nie odczytywali w swoich sercach: Tak, to, co mówi religia jest tym, czego potrzebujemy. Sama nauka, wyizolowana i zautonomizowana, nie wypełnia naszego życia. [...] Przeżywszy wielkie trwogi naszych czasów, dostrzegamy coraz wyraźniej, że musimy odnaleźć wewnętrzną równowagę i potrzebujemy także duchowego wzrostu ${ }^{38}$.

Ewangelia musi więc być wciąż na nowo wcielana, na podobieństwo wcielenia Jezusa, w taki świat, jaki jest zastany. „Chrześcijanin musi podjąć misję człowieka wobec świata, nie ulegając prometejskiej pokusie; jeszcze więcej: musi on współpracować w dziele zbawienia świata i człowieka ze świadomością, że jest ono niespełnialne wewnątrzświatowo" ${ }^{39}$. Z jednej strony chrześcijańskie zaangażowanie ma być zdeterminowane, a $\mathrm{z}$ drugiej pokornie zgadzać się na plan Boży. Kilka dziesięcioleci później niż Jan Paweł II wzywa do tego także papież Franciszek: „Kieruję apel do teologów, aby pełnili tę posługę [dociekań teologicznych] jak część zbawczej misji Kościoła. Konieczne jest jednak, aby leżał im na sercu ewangelizacyjny cel Kościoła oraz by nie zadowalali się teologią uprawianą przy stole" 40 . Teologia powinna być zatem kontekstualna, czyli ma uwzględniać różne konteksty w dociekaniach teologicznych, dążyć do komunikacji i wspólnoty z każdym społeczeństwem w służbie zbawieniu ${ }^{41}$. Jeśli teologia ma leczyć dzisiejszego człowieka, musi

${ }^{35}$ Por. Benedykt XVI, Światłość świata, tłum. P. Napiwodzki, Kraków 2011, s. 169.

${ }^{36}$ H.U. von Balthasar, Prawda jest symfoniczna, thum. I. Bokwa, Poznań 1998, s. 146.

37 Por. J. Mariański, Pozakościelne formy religijności, w: Postmodernizm wyzwanie dla chrześcijaństwa, dz. cyt., s. 66-67.

38 Benedykt XVI, Świattość świata, dz. cyt., s. 146.

39 H.U. von Balthasar, Prawda ..., dz. cyt., s. 147.

${ }^{40}$ Franciszek, Evangelii gaudium, dz. cyt., 133.

${ }^{41}$ Por. H. Waldenfelds, O Bogu, Jezusie Chrystusie i Kościele - dzisiaj. Teologia fundamentalna w kontekście czasów obecnych, tłum. A. Paciorek, Katowice 1993, s. 23-86. 
być zakorzeniona w egzystencji ${ }^{42}$, ponieważ problemy współczesnego świata najbardziej dotyczą codzienności.

\section{Kontekstualna teologia duchowości}

Jak zaznaczono wcześniej, teologia powinna uwzględniać konteksty życia współczesnego człowieka, zatem w sposób oczywisty będzie to dotyczyło także teologii życia wewnętrznego. Teologia duchowości obejmuje człowieka w zakresie jego życia Bożego przekazanego mu w sakramentach i ożywianego osobistym przyjmowaniem słowa Bożego. Ponieważ życie duchowe należy do świadomości osobowej, to zakłada poznanie człowieka we wszystkich jego wymiarach: środowisku społecznym, kulturalnym i historycznym. Życie duchowe jest życiem konkretnego człowieka, zatem dla teologii duchowości ważna jest wszelka wiedza o człowieku. I chociaż nauki humanistyczne nie są pierwszą zasadą teologii duchowości (jest nią dar życia nadprzyrodzonego), to nauki pomocnicze nie powinny być drugorzędne, ponieważ dar zawsze jest przyjmowany przez konkretny podmiot, w konkretnych, tak osobistych, jak i społeczno-kulturowych uwarunkowaniach ${ }^{43}$. Dlatego, „życie duchowe nie może polegać jedynie na spekulacjach, lecz musi angażować postawę praktyczną oraz brać pod uwagę sytuację osobistą człowieka wobec Boga. Innymi słowy, życie duchowe staje się doświadczeniem duchowym"44.

Doświadczenie duchowe w tradycji chrześcijańskiej występuje w licznych formach. Ciągle się odnawia, dlatego pojawiają się wciąż nowe formy duchowości, odpowiadające sytuacjom społecznym i kulturowym. Duch Święty czerpie z tego, co stare i nowe, by powodować ożywienie ${ }^{45}$.

\section{Chrześcijańska teologia codzienności jako próba odpowiedzi na potrzeby duchowe czlowieka w postmodernizmie}

Teologia codzienności Karla Rahnera z trudem odpowiadać będzie naukowym kryteriom teologicznym, ponieważ brakuje jej jasności i systematyczności wykładu. Trzeba jednak pamiętać, że Rahner stawiał jej zadania przede wszystkim praktyczne i pastoralne. Jego celem było pokazanie współczesnemu człowiekowi współczesnej drogi do Boga. Taką próbą jest właśnie jego

42 Por. J. Szymik, Teologia w świecie Pepsi-Coli, Warszawa 1999, s. 70.

${ }^{43}$ Por. Ch.A. Bernard, Wprowadzenie do teologii duchowości, thum. J. Machniak, Kraków 1996, s. 13.

44 Tamże, s. 21.

45 Por. tamże, s. 48. 
teologia codzienności. Należy ją rozumieć jako mające teologiczną głębię wezwanie do odkrywania nowych wymiarów zwyczajnego ludzkiego życia, a nie jako systematyczny wykład nowej dyscypliny teologicznej. Pomimo tych krytycznych uwag trzeba zaznaczyć, że sygnalizuje, często też rozwija, wiele cennych intuicji z punktu widzenia teologii duchowości życia codziennego, dlatego też głównie na tym autorze oprę się przy omawianiu interesującego mnie zagadnienia.

Rahner, mając na myśli codzienność, wymieniał: rutynę, przymus biologiczny, płytkość uczuć i przeżyć, stale powtarzane obowiązki i konieczności, spotkania tych samych ludzi ${ }^{46}$. Do istoty codzienności zaliczył także poczucie oddalenia od Boga pośród rzeczy całkowicie świeckich. Niemiecki teolog interesował się codziennością, ponieważ bliskie były mu: antropologiczna koncentracja teologii, przełamywanie dualizmu sacrum i profanum, szukanie Boga we wszystkim wzorem świętego Ignacego Loyoli, możliwość przeżywania doświadczenia duchowego przez każdego człowieka oraz całościowa koncepcja roli religii w życiu. By możliwe było pozytywne mówienie o codzienności, konieczna była akceptacja przekształconego świata wskutek sekularyzacji i zainteresowanie świeckimi członkami Kościoła. Rahner wychodzi od człowieka i jego doświadczeń, transcendentalności i codzienności, by dojść do Boga, który jest ukryty w tej codzienności, jest w niej obecny.

Rahner pisze o tym, że Bóg jest głęboko zakorzeniony w doświadczeniu człowieka, dlatego trzeba przyjąć tę codzienność, jeśli chce się przyjąć Boga. Uciekanie od codzienności jest także uciekaniem od człowieczeństwa, od samego siebie. „Nie możemy umknąć codzienności, gdyż zabieramy ją ze sobą, gdziekolwiek byśmy szli, jest bowiem nami - naszym codziennym sercem, gnuśnym duchem, małą miłością, która czyni lichym i zwykłym nawet to, co jest wielkie. I dlatego nasza droga prowadzić musi poprzez samą codzienność, poprzez jej obowiązki i niedole"47. To właśnie pozytywna ocena codzienności jest cechą charakterystyczną refleksji Rahnera. Dla niego szare wydarzenia zwykłych dni nie są czymś, od czego należy uciekać, bo to w nich można spotkać Boga. Dlatego tak wiele pisał o mistycyzmie życia codziennego, o łasce wśród codzienności i o samej codzienności jako łasce. Znane jest powiedzenie Rahnera, że „chrześcijanin przyszłości albo będzie mistykiem, albo go w ogóle nie będzie"48. Słowo mistyczny pojawia się w jego tekstach w dwóch

${ }^{46}$ K. Rahner, Eucharistie und alltägliches Leben, Schriften zur Theologie Bd. 7, Einsiedeln-Zürich-Köln 1966, s. 205, cyt. za: Z. Nosowski, Karla Rahnera teologia codzienności, „Studia Theologica Varsaviensia" 1992, nr 30/2, s. 91.

${ }^{47}$ K. Rahner, Kiedy się modlisz, w: Przez Syna do Ojca, thum. A. Morawska, D. Szumska, Kraków 1979, s. 68.

${ }^{48}$ K. Rahner, Im Gespräch, Bd . 2:1978-1982, 1983, s. 34, cyt. za: Z. Nosowski, Karla Rahnera teologia codzienności, „Studia Theologica Varsaviensia” 1992, nr 30/2, s. 93. 
znaczeniach: pierwsze oznacza najwyższe wzloty ducha ludzkiego, drugie odwołuje się do ignacjańskiego szukania Boga we wszystkim, do zakorzeniania wszystkiego w wymiarze misterium. To drugie rozumienie mistycyzmu jest znacznie częściej używane przez Rahnera i ma ono duże znaczenie w jego teologii codzienności. Bóg nie przychodzi z zewnątrz do naszej codzienności, by ją przemieniać. On jest już od początku milcząco w niej obecny. Mówiąc o chrześcijaninie przyszłości jako mistyku, Rahner ma na myśli człowieka żyjącego pełnią życia, także w jego najbardziej zwykłej i nużącej części, w tym życiu odnajdującego ślady Boga. Tak rozumiany mistycyzm nie jest zjawiskiem elitarnym, lecz dostępnym dla każdego człowieka.

Pierwszym krokiem ku otwarciu serca jest spojrzenie w prawdzie na swoje życie, dostrzeżenie własnej niewystarczalności i słabości. Człowiek doświadcza niebezpieczeństwa przepaści, nad którą się znajduje, a zarazem może dostrzec, że „owa przepaść przyjmuje go jako jego prawdziwe i przebaczające ocalenie"49, oferując mu tym samym nową interpretację tego faktu. Rzeczywistość zewnętrzna nie zmienia się, inna jest natomiast interpretacja przez to, że człowiek dostrzega w niej głębię i transcendencję. ,Wszystko więc sprowadza się do tego, jak odbywamy próbę codzienności. Może ona czynić człowieka codziennym, małostkowym. Może też - jak nic innego - wyzwalać go od niego samego" 50 .

Historia ludzkiej codzienności staje się historią łaski obecnej w tej codzienności, historią odkrywania mistycznego, nadprzyrodzonego wymiaru ludzkiego życia. Dzieje się tak, ponieważ istnieje łaska codzienności, to znaczy Boży dar, zawarty w najzwyklejszych wydarzeniach życia, który trwa, dopóki trwa ich zwyczajność i szarość, „prawdziwa głębia tylko pozornie powierzchownej i światowej codzienności wypełniona jest, może być wypełniona, przez Boga i Jego łaskę"51. Odkrycie tego drugiego wymiaru nazywa Rahner przewrotem kopernikańskim we współczesnej pobożności ${ }^{52}$. Przełom ten dokonał się zarówno w teologii, jak i w praktyce życia duchowego. Wnosi on do duchowości przekonanie, że „wszystko, co nie jest grzechem, ale co spełniane jest w sposób wolny i odpowiedzialny, jest dla chrześcijan znajdujących się w stanie łaski wydarzeniem tej łaski, częścią historii zbawienia, inspirowaną przez Ducha Bożego, przyjęciem Jego wieczności"53. Dzięki temu przeświadczeniu dokonała się zmiana podejścia do codzienności. Zamiast dążenia do sakralizacji dnia powszedniego Rahner mówił o zaakceptowaniu tej rzeczywistości i odszukaniu w niej wymiaru głębi, który jest w niej zawarty. Akcep-

\footnotetext{
49 K. Rahner, Podstawowy wykład wiary, tłum. T. Mieszkowski, Warszawa 1987, s. 114.

${ }^{50}$ K. Rahner, Kiedy się modlisz..., dz. cyt., s. 70.

${ }^{51}$ K. Rahner, Ryzyko chrześcijanina, thum. T. Mieszkowski, Warszawa 1979, s. 87.

${ }^{52}$ Por. K. Rahner, Ryzyko..., dz. cyt., s. 87.

${ }^{53}$ K. Rahner, Ryzyko..., dz. cyt., s. 86.
} 
tacja codzienności z jej ograniczeniami i koniecznościami jest aktem ludzkiej wolności, do którego człowiek jest wezwany. Posłuszna akceptacja losu sama już go przekształca, ,ponieważ i o ile dzieje się w łasce objawienia, jest już wiarą i (jeżeli osiąga swoją pełnię) miłością" ${ }^{54}$. Pełna akceptacja codzienności jest podstawowym warunkiem, który pozwoli dostrzec to, co rzeczywistość codzienna skrywa i stać się może miejscem doświadczenia Ducha Swiętego i łaski w codzienności ${ }^{55}$.

Jest prawdą wiary, że chrześcijanin poprzez każdy dobry czyn, poprzez każdy akt codziennej wierności wzrasta $\mathrm{w}$ łasce danej mu od Boga. Łaska bowiem nie jest terminem ograniczonym jedynie do życia modlitwą, a zamykanie łaski w sferze tego, co czysto duchowe, było w gruncie rzeczy niezgodne z chrześcijaństwem, ponieważ tym, którego obejmuje łaska i który staje się manifestacją łaski, jest cały człowiek ${ }^{56}$.

Przy takim zaakcentowaniu doświadczenie Boga stanowi głębię i istotę wszystkich doświadczeń duchowych i osobistych. W tej perspektywie zadaniem chrześcijańskiej teologii, zwłaszcza teologii mistyki, staje się wiarygodne i zrozumiałe pokazanie, że podstawowe elementy mistycznego doświadczenia transcendencji są obecne $\mathrm{w}$ prostych wydarzeniach życia chrześcijańskiego. W teologii codzienności Rahnera powtarzającym się wątkiem jest uczciwe wypełnianie obowiązków. Element ten dobrze pozwala ukazać specyfikę jego myśli. Rahner mówi o tym, że w życiu łaską codzienności potrzebne są cnoty codzienności, wiele o nich pisał, ale nie przedstawił żadnej systematyzacji cnót codzienności ${ }^{57}$, nie klasyfikował ich, tłumacząc to ich zależnością od konkretności życia, a więc od zmiennej codzienności, która wymaga coraz to nowych cnót.

Także na modlitwę Rahner patrzył zgodnie z postulatem antropologicznej koncentracji teologii, czyli przez pryzmat modlącego się człowieka. Stając do modlitwy, wobec Boga, człowiek jest

konkretnym człowiekiem, a nie abstrakcyjnym ideałem, nie czysto religijnym człowiekiem, który pragnie tylko Boga. Jest to człowiek codziennych, świeckich i prozaicznych życiowych potrzeb i niepokojów. I takim też powinien stanąć wobec Boga w modlitwie, taki jaki jest, jaki jest w swoim niewytłumaczalnym i by-

${ }^{54}$ K. Rahner, H. Vorgrimler, Mały słownik teologiczny, tłum. T. Mieszkowski, P. Pachciarek, Warszawa 1987, s. 209.

55 Por. Z. Nosowski, Karla Rahnera teologia codzienności, „Studia Theologica Varsaviensia” 1992, nr 30/2, s. 100.

${ }^{56}$ K. Rahner, Eucharistie und alltägliches Leben..., dz. cyt., s. 102.

57 Por. Z. Nosowski, Karla Rahnera teologia..., dz. cyt., s. 112-114. 
najmniej nie dającym się sprowadzić do czystej religijności pędzie życia i w swoich potrzebach życiowych, wiedząc, że Bóg sam chce, żeby takim był ${ }^{58}$.

Rzeczywistość jawi się jako jedność tego, co cielesne, z tym, co duchowe i transcendentne. Co za tym idzie, ,modlitwy w jej najgłębszej istocie nie można uważać za coś dodatkowego i osobnego, z czym mamy do czynienia również obok wielu innych spraw. Trzeba ją rozumieć jako wyraz i realizację całości naszej egzystencji, nawet jeżeli nominalna modlitwa zajmuje nam tylko małą cząstkę naszego czasu"59. Wyrasta z życia i do życia prowadzi. Modlitwa wyraża przeżywane problemy, a z drugiej strony życie samo może stać się modlitwą bez słów. Od tego już tylko krok do wniosku, że należy modlić się codziennością. W takiej praktyce chodzi o dostrzeganie Bożego wymiaru rzeczywistości, o ćwiczenie na co dzień cnót wiary, nadziei i miłości, co sprawi, że codzienność upodobni się do modlitwy. Gdy miłość znajdzie swój najbardziej powszedni wyraz, gdy życie człowieka wierzącego

będzie rodzeniem się miłości, aż cała codzienność stanie się jej oddechem, oddechem wierności i tęsknoty, wiary, gotowości, oddania Bogu. Wtedy rzeczywiście stanie się ona modlitwą bez słów, choć pozostanie tym czym jest: ciężką, zwykłą, prozaiczną i szarą dolą powszednią. I musi taką pozostać, gdyż tylko wtedy służy miłości Boga odbierając nam samych siebie ${ }^{60}$.

Teologia codzienności Karla Rahnera to najlepszy przykład teologii tu i teraz, refleksji teologicznej gotowej podejmować wszystkie wątki życia ludzkiego.

W końcu XX wieku panowało przekonanie, że decydującym czynnikiem kulturotwórczym naszej epoki będzie pragmatyczny konsumpcjonizm. Bez wątpienia takie zjawisko dziś istnieje. Jest jednak podporządkowane prawom rynku i sztucznie wzmacniane przez reklamę, ale czysto naturalistyczne antropologie nie przewidziały powrotu w stronę sacrum, nawet jeśli wyraża się on tylko na poziomie substytutów metafizyki i mistyki w nurcie New Age. Oznacza to, że ludzkich tęsknot nie da się sprowadzić tylko do poziomu pragmatyki i konsumpcji, ale ukazuje prawdę o człowieku jako o istocie z natury religijnej. Należy jednak liczyć się z tym, że mentalność kształtowana w kręgu

58 K. Rahner, Ryzyko..., dz. cyt., s. 60.

59 Tamże, s. 61-62.

60 K. Rahner, Kiedy się modlisz..., dz. cyt., s. 60. 
wpływów postmodernizmu w istotny sposób rzutuje na sposób przeżywania otwarcia na transcendencję. Dlatego na obecnym etapie rozwoju kultury konieczne jest poszukiwanie nowych form ekspresji prawd, tak by mogły dotrzeć do współczesnego odbiorcy. Niektóre propozycje dotyczące duchowości postmodernistycznej ukazują taką szansę i nie należy jej zbyt pochopnie odrzucać. Choćby dowartościowanie przez postmodernizm pozaracjonalnych form odkrywania sensu może okazać się również ważną formą ekspresji treści istotnych dla naszego przeżywania wiary religijnej. Uzasadnione wydaje się oczekiwanie, że może istnieć również wersja postmodernistycznego życia spójnego z duchowością chrześcijańską. Do poszukiwania takiej możliwości skłania istotny $\mathrm{w}$ duchowych doświadczeniach postmodernistycznego człowieka element niespełnienia.

Człowiek współczesny, ukształtowany przez: postmodernistyczne wizje czasu, przestrzeni, zwątpienia w możliwość poznania prawdy, poczucie tymczasowości, osamotnienia, obietnice zaspokojenia wszystkich swoich potrzeb przez konsumowanie coraz to nowych dóbr materialnych i metafizycznych, często odkrywa w sobie pewną niezaspokajalną tęsknotę. Drogą do odkrycia spełnienia i sensu w świecie, który wydaje się zupełnym chaosem, może być odkrycie obecności Boga w każdym momencie i miejscu codzienności. Obecność ta nie jest obca codzienności, oddzielona od niej, ale realizuje się poprzez ową zwyczajności szarość. Nie wymaga porzucenia życia, pracy, obowiązków, ale przez przyjęcie w ten sposób wcielonego w codzienność Boga staje się Jego przebywaniem i przemienianiem tej rzeczywistości, w której człowiek żyje. Dobre wypełnianie obowiązków i podjętych zobowiązań jest też drogą do świętości. Wobec nieustannej zmienności wartości, punktów odniesienia, środowiska Bóg jest tym, który w każdym momencie i miejscu pozostaje niezmienny i na Nim człowiek będzie mógł oprzeć swoją tożsamość. Będzie mógł czuć się mniej niepewny co do sensu swojego życia i sensu kreowania rzeczywistości. Bóg nadaje sens temu, co wydaje się bez znaczenia. Staje się swoistą odtrutką na postmodernistyczną pogoń za wrażeniami. Odkrywanie Chrystusa w codzienności, uczenie się od Niego miłości nie może i nie powinno pozostać bez wpływu na relację do drugiego człowieka, co wobec współczesnego wyobcowania, które jest konsekwencją skrajnego indywidualizmu, może skutkować odkryciem na nowo wartości relacji, tak indywidualnych, jak wspólnotowych.

Możliwość prowadzenia życia duchowego w kontekście przemian postmodernistycznych jest tematem rozległym. Moim zamiarem nie było udzielenie wyczerpującej odpowiedzi, ale nakreślenie możliwości uprawiania teologii duchowości, a także praktykowania życia duchowego w kontekście postmodernizmu. Sama teologia duchowości nie musi być kontestująca ani w pełni i bezkrytycznie próbować się dostosować do mentalności człowieka. 
Teologia i życie duchowe powinny z człowieka wydobywać to wszystko, co pomaga mu wzrastać ku zbawieniu. Czasami wymaga to odrzucenia czegoś z rzeczywistości społeczno-kulturowej, w której się znajduje, czasami sytuacja może zostać włączona na drodze przejęcia jako element osobistej historii życia duchowego, punkt odniesienia, jako źródło nadziei. Codzienność, także ta $\mathrm{w}$ postmodernistycznym kontekście, nie jest zbędnym balastem, ale drogą wzrostu duchowego i świętości.

\title{
KARL RAHNER'S THEOLOGY OF DAILY LIFE AS A RESPONSE
} TO SPIRITUAL NEEDS OF MAN IN THE POSTMODERN WORLD

\begin{abstract}
The article attempts to present Rahner's daily theology as a response to the spiritual needs of man conditioned by postmodern transformations. For this purpose, the socio-cultural aspects of postmodernism and their anthropological consequences are discussed. They have become the basis for presenting Rahner's contextual theology as taking into account the conditioning of modern man.
\end{abstract}

Słowa kluczowe: postmodernizm; duchowość; codzienność; Rahner; teologia kontekstualna

Keywords: postmodernism; spirituality; daily life; Rahner; contextual theology

\section{BIBLIOGRAFIA}

\section{Dokumenty}

Franciszek, Evangelii gaudium, Częstochowa 2013.

Jan Paweł II, Christifideles laici http://www.opoka.org.pl/biblioteka/W/WP/jan_pawel_ii/adhortacje/christifideles.html [dostęp 17.10.2017].

Jan Paweł II, Przemówienie, Manila, 14.01.1995, http://nauczaniejp2.pl/dokumenty/wyswietl/ id/688, [dostęp: 17.10.2017].

Jan Paweł II, Przemówienie, Puebla, 28.01.1979, Dzieła zebrane, t XII, Kraków 2009.

Papieska Rada Kultury, Papieska Rada ds. Dialogu Międzyreligijnego, Jezus Chrystus dawca wody żywej. Chrześcijańska refleksja na temat New Age, Kraków 2003.

\section{Publikacje książkowe}

Balthasar H.U. von, Prawda jest symfoniczna, tłum. I. Bokwa, Poznań 1998. 
Baran B., Postmodernizm i końce wieku, Kraków 2003.

Baran B., Postmodernizm, Kraków 1992.

Bauman Z., Dwa szkice o moralności ponowoczesnej, Warszawa 1994.

Bauman Z., Ponowoczesność jako źródlo cierpień, Warszawa 2000.

Benedykt XVI, Świattość świata, tłum. P. Napiwodzki, Kraków 2011.

Bernard Ch.A., Wprowadzenie do teologii duchowości, tłum. J. Machniak, Kraków 1996.

Dębowski J., Postmodernizm a religia, „Res Humana” 4(1995), s. 4-9.

Falczyński Z., Teologia w kontekście ponowoczesności, w: Postmodernizm wyzwanie dla chrześcijaństwa, red. Z. Sareło, Poznań 1995, s. 99-114.

Garrido J.J., Misja chrześcijanina w czasach kryzysu kultury, „Communio” 1994, nr 6, s. 59-94.

Guzowska B., Duchowość ponowoczesna, idee, perspektywy, prognozy, Rzeszów 2011.

Kłoczowski J.A., Chrześcijanin XXI wieku, „Znak” 1995, nr 3, s. 56-60.

Lata J.A., Lęk przed pustka i bezsensem, „Communio” 1994, nr 6, s. 40-45.

Luckmann T., Niewidzialna religia, tłum. L. Bluszcz, Kraków 2006.

Mariański J., Pozakościelne formy religijności, w: Postmodernizm wyzwanie dla chrześcijaństwa, red. Z. Sareło, Poznań 1995, s. 60-79.

Morawski S., W mrokach postmodernizmu. Rozmyślania rekolekcyjne, w: Dokąd zmierza współczesna humanistyka?, red. T. Kostyrko, Warszawa 1994, s. 5-34.

Napiórkowski S.C., Jak uprawiać teologię, Wrocław 1994.

Nosowski Z., Karla Rahnera teologia codzienności, „Studia Theologica Varsaviensia” 1992, nr 30/2, s. 89-119.

Pawlak Z., Filozoficzne aspekty ruchu postmodernistycznego, w: Globalopolis. Kosmiczna wioska. Szanse i zagrożenia, red. R. Borkowski, Warszawa 2003, s. 28-58.

Rahner K., Podstawowy wyklad wiary, tłum. T. Mieszkowski, Warszawa 1987.

Rahner K., Przez Syna do Ojca, tłum. A. Morawska, D. Szumska, Kraków 1979.

Rahner K., Ryzyko chrześcijanina, tłum. T. Mieszkowski, Warszawa 1979.

Rahner K., Vorgrimler H., Mały słownik teologiczny, tłum. T. Mieszkowski, P. Pachciarek, A. Skowronek, Warszawa 1987.

Sareło Z., Postmodernistyczny styl myślenia i życia, w: Postmodernizm wyzwanie dla chrześcijaństwa, Poznań 1995, s. 9-27.

Strzelczyk G., Po co zbawienie? Po co Kościót?, w: Wielkie tematy teologii, red. E. Kiedio, Z. Nosowski, Warszawa 2015, s. 13-30.

Szymik J., Teologia w świecie Pepsi-Coli, Warszawa 1999.

Vloet J. van der, Wiara wobec wyzwań postmodernizmu, „Communio” 1994, nr 6, s. 60-67.

Waldenfelds H., O Bogu, Jezusie Chrystusie i Kościele - dzisiaj. Teologia fundamentalna w kontekście czasów obecnych, tłum. A. Paciorek, Katowice 1993.

Życiński J., Bóg postmodernistów, Lublin 2001.

JUSTYNA NOWICKA - zdobyła dyplom magistra teologii na Wydziale Teologicznym UAM, broniąc pracy zatytułowanej: Teologia apofatyczna Pseudo-Dionizego Areopagity i próba jej przezwyciężenia przez Tomasza z Akwinu. Podczas studiów odbyła roczny staż na UK w Pradze. Autorka artykułu Uzależnienia w książce Spowiedź i kierownictwo duchowe w sytuacjach szczególnych (2012), a także wielu artykułów popularyzujących życie chrześcijańskie, publikowanych m.in. w „Przewodniku Katolickim”, „Oremusie”, na portalach wiara.pl i misyjne. pl. Aktywnie działa w Klubie Tygodnika Powszechnego w Poznaniu oraz Przymierzu Miłosierdzia. Obecnie doktorantka w Zakładzie Teologii Moralnej, Duchowości i Katolickiej Nauki Społecznej na Wydziale Teologicznym UAM. 